University of Nebraska - Lincoln

DigitalCommons@University of Nebraska - Lincoln

Papers in the Earth and Atmospheric Sciences

Earth and Atmospheric Sciences, Department

2006

\title{
Burrows Dug by Large Vertebrates into Rain-Moistened Middle Jurassic Sand Dunes
}

David B. Loope

University of Nebraska, Lincoln, dloope1@unl.edu

Follow this and additional works at: https://digitalcommons.unl.edu/geosciencefacpub

Part of the Earth Sciences Commons

Loope, David B., "Burrows Dug by Large Vertebrates into Rain-Moistened Middle Jurassic Sand Dunes" (2006). Papers in the Earth and Atmospheric Sciences. 212.

https://digitalcommons.unl.edu/geosciencefacpub/212

This Article is brought to you for free and open access by the Earth and Atmospheric Sciences, Department of at DigitalCommons@University of Nebraska - Lincoln. It has been accepted for inclusion in Papers in the Earth and Atmospheric Sciences by an authorized administrator of DigitalCommons@University of Nebraska - Lincoln. 


\title{
GEOLOGICAL NOTE
}

\section{Burrows Dug by Large Vertebrates into Rain-Moistened Middle Jurassic Sand Dunes}

\author{
David B. Loope \\ Department of Geosciences, 214 Bessey Hall, University of Nebraska, Lincoln, Nebraska 68588-0340, U.S.A. \\ (e-mail: dloope1@unl.edu)
}

\begin{abstract}
A B S T R A C T
In south-central Utah, eolian cross-strata of the Escalante Member of the Entrada Sandstone contain inclined, cylindrical burrows up to $63 \mathrm{~cm}$ in diameter and $305 \mathrm{~cm}$ long. Of the 14 large tunnels located during this study, 12 descend from second- and third-order bounding surfaces that formed on the lee slopes of large dune ridges, well above the water table. The tunnels are inclined $15^{\circ}-22^{\circ}$; one tunnel ends in an expanded chamber. Eolian cross-strata fill proximal portions of four of the tunnels and indicate that after abandonment, sand drifts migrated as much as a meter into the open shafts. Structureless sand and breccia blocks that were generated by roof collapse fill other tunnels. Animals dug the tunnels in rain-moistened, cohesive sand. The burrows may have served as temporary shelters from severe diurnal conditions in the shadeless, subtropical Entrada dune field.
\end{abstract}

\section{Introduction}

Puzzling over the relative rarity of vertebrate burrows known from the stratigraphic record, Voorhies (1975) concluded that two geological factors may be especially important: (1) most modern burrowers prefer well-drained substrates from upland sites that are seldom preserved in the geologic record because they are distant from sites of sediment aggradation; and (2) distinctions between the fill of fossil burrows and the enclosing matrix can be very subtle, thereby making burrows nearly invisible.

Like other sediment accumulations, eolian strata must be deposited in subsiding sedimentary basins in order to be preserved in the rock record. Unlike other aggradational surfaces, however, the lee slopes of migrating dunes lie high above the water table. Biogenic disruptions of thin eolian strata are sharply delineated and are therefore likely to be observed and recognized. This article reports large, distinct burrows preserved in a Middle Jurassic sandstone that was deposited by windblown dunes. All of the 14 tunnels described here were excavated into well-drained, thinly stratified material; some 2006. of them were subsequently filled by small-scale eolian cross-strata.

From Permian and Triassic strata in South Africa, Smith (1987) described sandstone casts of helical burrows that had been excavated in subaerially exposed fluvial mudstones and filled by coarser sediment. The casts range up to $16 \mathrm{~cm}$ in diameter and were made by synapsid reptiles (which were found as articulated fossils in some casts). Hasiotis et al. (2004) recently reported a large variety of Late Triassic and Late Jurassic vertebrate burrows that cross-cut fluvial sand-mud interbeds. Some of the gently inclined burrows reach several decimeters in diameter and thus are similar in size and form to those discussed here. In all of the aforementioned burrows, the sand-filled shafts are easily discerned from the lithologically distinct matrix. The burrows were constructed near flowing water, provided protection for the burrower from desiccation, and were quickly filled during fluvial floods (Smith 1987; Hasiotis et al. 2004).

Of the numerous thick eolian sandstones that accumulated during the late Paleozoic and early Mesozoic on western, near-equatorial Pangaea (now the Colorado Plateau; Kocurek 1988; Loope et al. 2004), the Escalante Member of the Entrada 


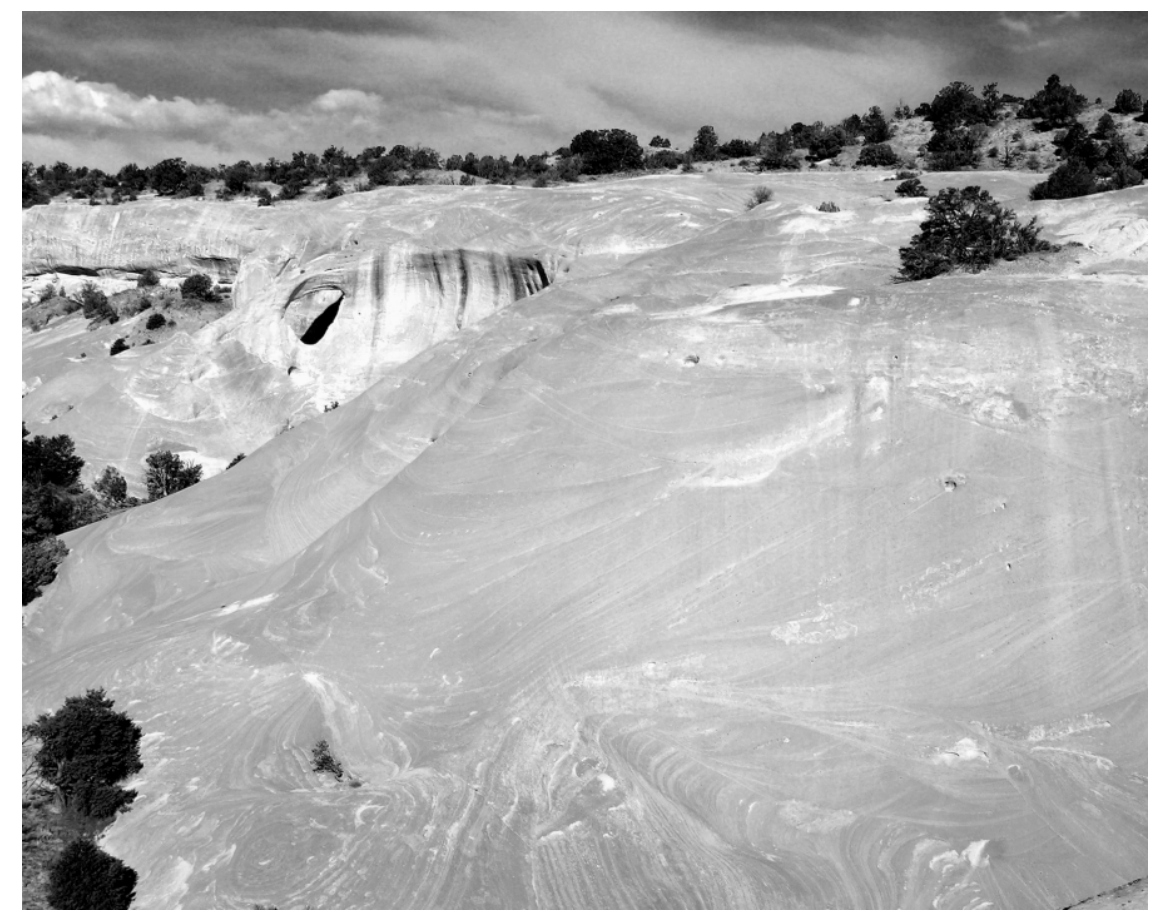

Figure 1. Escalante Member of the Entrada Sandstone at Cedar Wash Arch (site 2 in fig. 2). About $30 \mathrm{~m}$ of crossstrata are exposed (fig. 3).

Sandstone (Middle Jurassic; fig. 1) is one of the youngest. It accumulated as the supercontinent was breaking up, when the center of the plateau had reached about $20^{\circ} \mathrm{N}$ (Steiner 2003). Although some of the eolian sandstones on the plateau preserve few, if any, signs of life (e.g., the Permian White Rim Sandstone), others, including the Permian Coconino and Cedar Mesa Sandstones (McKee 1934; Loope 1984) and the Jurassic Navajo Sandstone (Lockley and Hunt 1995; Loope and Rowe 2003; Loope 2006), preserve abundant rhizoliths, invertebrate burrows, and vertebrate tracks. Until very recently, however, no vertebrate burrows had been described from these strata (Loope 2005).

The Escalante Member of the Entrada Sandstone is 65-85 $\mathrm{m}$ thick (Thompson and Stokes 1970) and crops out along the northeast margin of the Kaiparowits Plateau in south-central Utah (figs. 1-3). The Entrada Sandstone, including the Escalante Member, is largely composed of compound crossstrata (sets of cross-strata that are bounded by downwind-sloping erosion surfaces). Many of the erosion surfaces in the Entrada were generated by relatively small bedforms that migrated and climbed over the leeward slopes of large dune ridges (the second-order bounding surfaces of Brookfield 1977 and Kocurek 1981; fig. 4a). Gently dipping erosion surfaces, however, can also be cut after reversals in wind direction (the reactivation surfaces or third-order bounding surfaces of Brookfield (1977; fig. 4b). Large burrows were found at three

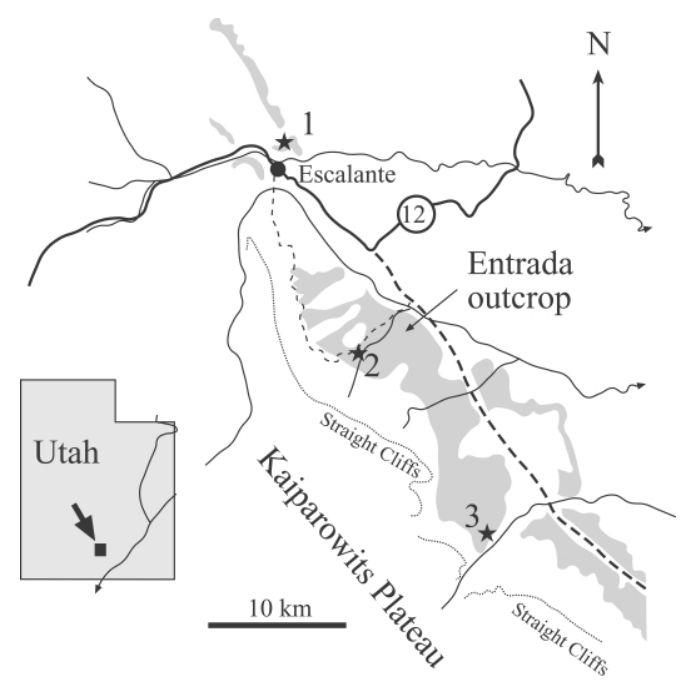

Figure 2. Map showing distribution of the Entrada Sandstone and the locations of the three study sites: (1) Dumas Ranch, (2) Cedar Wash Arch, and (3) 20-Mile Wash. 


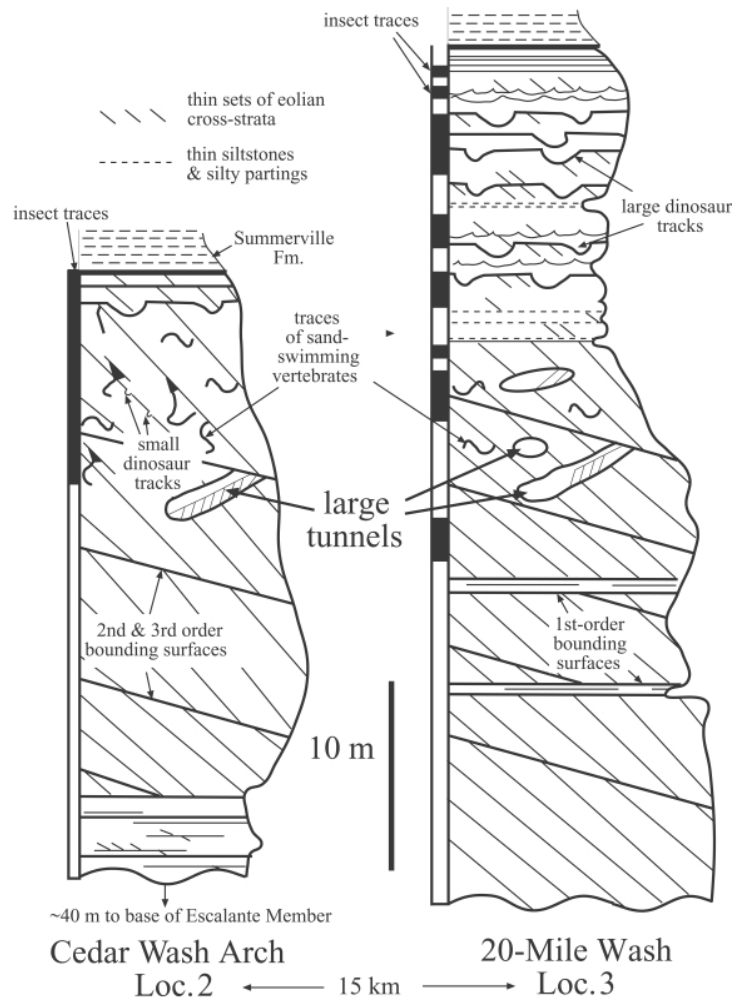

Figure 3. Stratigraphic sections from sites 2 and 3 (fig. 2) showing the distribution of Middle Jurassic trace fossils: insect burrows, dry-sand traces of sand-swimming vertebrates, large tunnels dug into moist dune sand, and tracks of large sauropod and theropod dinosaurs and small tetrapods.

sites (fig. 2). Twelve of the 14 burrows extend downward from prominent inclined erosion surfaces; two (table 1, burrows 1-1 and 1-2) lie below a horizontal erosion surface, and only one burrow (2-2) cuts an erosional surface. A fundamental difference between the two types of inclined erosion surface is that the reactivation surfaces /generated by wind reversals) are isochronous (they were generated during a single, short-lived event), but the erosion surfaces produced by migrating bedforms are diachronous (fig. 4). Burrow distribution suggests that nearly all of the burrow-associated erosion surfaces (but only a minority of the surfaces in the Entrada) are isoschronous and were generated by wind reversals (see "Interpretation").

Downslope-directed compressional faults and breccia beds are present in some thick sets of crossstrata at site 2 (fig. 5A). These resemble features in the Navajo Sandstone that have been interpreted as mass movements generated by heavy rainfall events (Loope et al. 2001).
Dry, cohesionless dune sand is unsuitable for the semipermanent burrows needed for nesting and repeated sheltering. Many small vertebrates in modern sand seas are adapted for sand swimming, and they move efficiently through dune sand while foraging. The Entrada cross-strata that contain largediameter burrows (the subject of this article) also contain much more abundant, smaller $(25-35 \mathrm{~mm}$ diameter) traces of sand-swimming reptiles that were made in cohesionless sand (Loope 2005).

Trace fossils in the Entrada Sandstone record a robust, diverse ecosystem. Small (5-mm diameter) cylindrical traces made by insects are abundant in many exposures (fig. 3). Rhizoliths that are defined by a perimeter of small invertebrate traces (the "rhizolith-engulfing" traces of Hasiotis et al. [2004] and Loope [2005]) are common at site 3. Large dinosaur tracks (fig. 3) are preserved in abundance at site 3 and at one small outcrop at site 2. Small, widely scattered, and poorly preserved vertebrate tracks are visible within some sets of cross-strata exposed at site 2 (figs. 3, 5B).

When moist, dune sand is cohesive and is easily excavated by scratch-digging vertebrates (Hildebrand 1985), but when the sand dries, such burrows
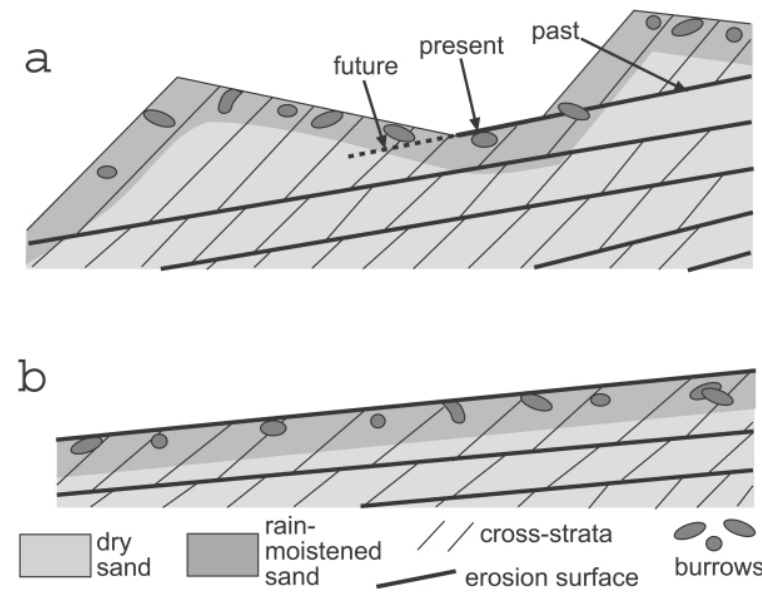

Figure 4. Origin of erosion surfaces and large burrows excavated in rain-moistened eolian sand. $a$, Migrating bedforms generate diachronous erosion surfaces. If dunes and interdunes are wetted and burrowed, most burrows will be destroyed when bedforms continue their migration. Only a small number of widely scattered burrows will lie below erosion surfaces, and some of these will cut the erosion surfaces. $b$, Short-lived reversals of the wind direction can generate extensive isochronous erosion surfaces. If the surface is wetted, burrows will extend downward from the erosion surface. Burrows are unlikely to cut across the erosion surface after it is buried. 
Table 1. Locations, relations to bounding surfaces, relevant figures, dimensions, and orientations of 14 large burrows located for this study

\begin{tabular}{|c|c|c|c|c|c|c|}
\hline $\begin{array}{l}\text { Site name and } \\
\text { burrow number }\end{array}$ & $\begin{array}{l}\text { Latitude and longitude } \\
\text { (WGS 84) }\end{array}$ & Figure & $\begin{array}{c}\text { Maximum } \\
\text { diameter } \\
(\mathrm{cm})\end{array}$ & $\begin{array}{l}\text { Maximum } \\
\text { length } \\
\text { (cm) }\end{array}$ & $\underset{\substack{\text { Dip } \\
\text { magnitude }}}{\left.{ }^{\circ}\right)}$ & $\begin{array}{l}\text { Azimuth } \\
\text { of long } \\
\text { axis }\left(^{\circ}\right)\end{array}$ \\
\hline \multicolumn{7}{|l|}{ Dumas Ranch: } \\
\hline $1-1$ & $37^{\circ} 47.127^{\prime} \mathrm{N}, 111^{\circ} 35.803^{\prime} \mathrm{W}$ & & 51 & 241 & 22 & $\ldots$ \\
\hline $1-2$ & $37^{\circ} 47.127^{\prime} \mathrm{N}, 111^{\circ} 35.803^{\prime} \mathrm{W}$ & & 46 & 66 & $\ldots$ & $\ldots$ \\
\hline \multirow{2}{*}{\multicolumn{7}{|c|}{$\begin{array}{c}\text { Cedar Wash } \\
\text { Arch: }\end{array}$}} \\
\hline & & & & & & \\
\hline $\begin{array}{l}2-1 \\
2-2\end{array}$ & $37^{\circ} 39.937^{\prime} \mathrm{N}, 111^{\circ} 31.848^{\prime} \mathrm{W}$ & 6 & 38 & $\begin{array}{l}122 \\
142\end{array}$ & $\begin{array}{l}10 \\
18\end{array}$ & $2 / 0$ \\
\hline $2-3$ & $37^{\circ} 39.937^{\prime} \mathrm{N}, 111^{\circ} 31.848^{\prime} \mathrm{W}$ & 6 & 46 & $\begin{array}{r}142 \\
89\end{array}$ & $\begin{array}{l}18 \\
18\end{array}$ & 165 \\
\hline \multicolumn{7}{|l|}{ 20-Mile Wash: } \\
\hline $3-1$ & $37^{\circ} 33.048^{\prime} \mathrm{N}, 111^{\circ} 25.415^{\prime} \mathrm{W}$ & $8 a, 8 c, 8 d$ & 28 & 198 & 22 & 145 \\
\hline $3-2$ & $37^{\circ} 33.048^{\prime} \mathrm{N}, 111^{\circ} 25.415^{\prime} \mathrm{W}$ & $8 b$ & 28 & 127 & 10 & 165 \\
\hline $3-3$ & $37^{\circ} 33.048^{\prime} \mathrm{N}, 111^{\circ} 25.415^{\prime} \mathrm{W}$ & & 30 & 163 & 0 & 25 \\
\hline $3-4$ & $37^{\circ} 33.057^{\prime} \mathrm{N}, 111^{\circ} 25.363^{\prime} \mathrm{W}$ & & 53 & 150 & 19 & 210 \\
\hline $3-5$ & $37^{\circ} 33.057^{\prime} \mathrm{N}, 111^{\circ} 25.363^{\prime} \mathrm{W}$ & 7 & $38-63$ & 305 & 16 & 180 \\
\hline $3-6$ & $37^{\circ} 33.048^{\prime} \mathrm{N}, 111^{\circ} 25.385^{\prime} \mathrm{W}$ & & 34 & 51 & & \\
\hline $3-7$ & $37^{\circ} 33.048^{\prime} \mathrm{N}, 111^{\circ} 25.385^{\prime} \mathrm{W}$ & $9 A$ & 38 & 81 & 5 & 310 \\
\hline $3-8$ & $37^{\circ} 33.048^{\prime} \mathrm{N}, 111^{\circ} 25.385^{\prime} \mathrm{W}$ & & 38 & 71 & 16 & 150 \\
\hline $3-9$ & $37^{\circ} 33.048^{\prime} \mathrm{N}, 111^{\circ} 25.385^{\prime} \mathrm{W}$ & & 63 & 170 & 8 & 145 \\
\hline
\end{tabular}

are subject to collapse and infilling during windstorms. The vertebrate burrows described here may have been made by animals that, despite being residents of the dune field, burrowed only under favorable conditions. Another possibility is that the burrowers entered the dune field only during unusually wet intervals, a phenomenon seen after prolonged rain events in modern dune fields (Seely and Louw 1980).

\section{Burrow Description}

Burrow Size and Shape. Burrows are typically cylindrical, with diameters up to $63 \mathrm{~cm}$ and lengths up to $305 \mathrm{~cm}$ (table 1; figs. 6-9). One transverse section is oval, but three others are circular. Burrow 3-5 (fig. 7) has an enlarged chamber at its distal end that reaches $63 \mathrm{~cm}$ in diameter. The upper portions of all burrows are inclined $16^{\circ}-22^{\circ}$ to the horizontal.

Burrow Distribution. All 14 of the burrows observed for this study (table 1) were excavated in eolian cross-strata that lie within the upper half of the Escalante Member (fig. 3). The burrows were excavated in clusters; of the 14 burrows located for this study, only one occurs in isolation $(2-1$; table 1). Twelve of the 14 burrows terminate upward at planar erosion surfaces that lie between relatively thin sets of eolian cross-strata, and they dip about $10^{\circ}$. One burrow (2-2; table 1 ; fig. 6$)$ cuts an erosion surface and was excavated directly into one of the small superimposed dunes that lay about $10 \mathrm{~m}$ above the base of the larger dune. Two other bur- rows (1-1 and 1-2; table 1) lie below a nearly horizontal first-order bounding surface.

Burrow Fills. Three types of material fill the burrows: (1) cross-strata (figs. 7-9), (2) breccia (fig. 9A), and (3) structureless sand. The burrows with crossstratified fills are aligned northwest-southeast; three have entrances to the northwest and one to the southeast (table 1). Cross-strata extend as much as $1.5 \mathrm{~m}$ from the burrow entrance. Cross-strata strike perpendicular to the burrow walls and dip away from the entrance (figs. 8, 9). Breccia blocks within the burrows range up to $15 \mathrm{~cm}$ in diameter and fill some burrows nearly completely; in other burrows, isolated blocks lie within cross-strata (fig. $9 A$ ) or structureless sand. Both the breccia blocks and the structureless sand typically contain abundant coarse sand. In three burrows, a "cap" composed of coarse sand is the final fill (figs. $8 a, 9 B$ ).

\section{Interpretation}

The large burrows described here were excavated in cohesive sand, presumably after precipitation events or wet seasons. Two other independent lines of evidence show that the dunes were at least occasionally wetted by rainfall: (1) rooted plants high on the dune slopes (indicated by the distribution of rhizoliths) required vadose water from precipitation events, and (2) slumped and brecciated crossstrata (fig. 5A) reflect wet conditions on steep dune slopes. In subtropical deserts, the main opportunity for rainfall events (or a rainy season) comes with 

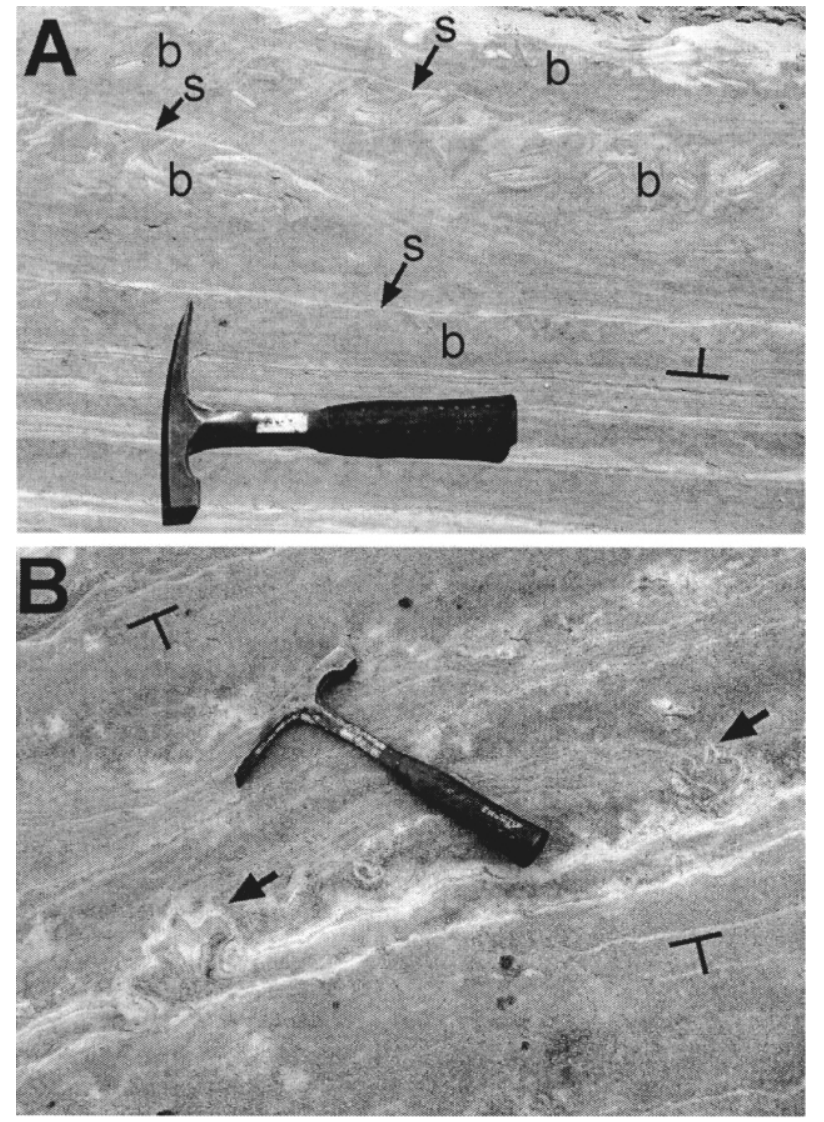

Figure 5. Physical and biogenic sedimentary structures in the Escalante Member at Cedar Wash Arch (site 2, figs. 2, 3). A, Plan view of cross-strata that dip toward top of photograph. Brecciated cross-strata $(b)$ and shear surfaces $(s)$ were generated during mass wasting of the slip face; presumably, they were triggered by positive pore water pressure that developed during a heavy rainfall event (see Loope et al. 2001). B, Poorly formed vertebrate tracks (arrows) seen in a horizontal cross section of eolian cross-strata that dip steeply to the lower right. Such structures are fairly common, but well-formed tracks are absent. These tracks are of a size appropriate for the burrow maker.

the arrival of the intertropical convergence zone (ITCZ). In modern-day North Africa, rainfall diminishes very rapidly at the southern edge of the Sahara, at about $15^{\circ} \mathrm{N}$ (Buckle 1996). The limit of ITCZ migration shifted northward, however, by over $1000 \mathrm{~km}$ between the glacial maximum and the mid-Holocene climatic optimum (Yan and Petit-Maire 1994).

The cross-strata that lie inside the burrows oriented northwest-southeast (table 1, burrows 3-1, $3-2,3-5$, and $3-7)$ were formed after the dune sur- faces had dried sufficiently to allow sand transport. During saltation, grains of fine to medium sand size move forward at high velocity in a series of jumps. When these grains return to the sandy substrate, they eject other fine and medium grains and push or roll coarser grains (the much slower movement called "creep"). Saltating grains impact the substrate at an angle of between $6^{\circ}$ and $20^{\circ}$ (Pye and Tsoar 1990). Thus, after burrows were abandoned, both northwesterly and southeasterly winds swept fine saltating grains over their entrances; many grains with downward trajectories entered the burrow mouths and built sand drifts that migrated deep into the open structures. The coarse sand within the burrow "caps" (figs. 8, 9B) was preferentially trapped during the final stage of burrow filling; although fine-grained saltating sand bypassed the shallow surface declivities at the mouths of nearly full burrows, many coarser grains moving by creep did not.

The identity of the animals that produced the burrows and the poorly preserved tracks (fig. $5 B$ ) is unknown. Although the Late Jurassic of western United States is very rich in skeletal material, the only body fossils of Middle Jurassic nonmarine tetrapods that have been reported from North America are two crocodylomorphs, one of which, a $20-\mathrm{cm}$ long specimen found in southeastern Utah, is from the Entrada Sandstone (Hunt and Lockley 1995). Many more vertebrate fossils are preserved in the Early Jurassic Navajo Sandstone (see review in Irmis 2005). Winkler et al. (1991) described the partial skeleton of a tritylodontid synapsid from a Navajo interdune sandstone. This specimen displayed a strikingly large olecranon process on its ulna, and Winkler et al. (1991) interpreted the animal as a long-bodied $(\sim 1 \mathrm{~m})$, herbivorous scratch-digger, well adapted to digging in soft dune sand. Much of what we know about Early and Middle Jurassic vertebrates, however, comes from tracks (Lockley 1998). Tracks of large dinosaurs are present in the thin-bedded uppermost part of the Escalante Member (Doelling et al. 2000; fig. 3), but the poorly preserved tracks described here (fig. $5 B$ ) are the first ones reported from thick sets of Entrada crossstrata. Although these tracks are about the right size to be those of the burrower, no tracks are directly associated with the burrows.

From the interbedded sandstone and mudstone of the Salt Wash Member of the Morrison Formation (upper Jurassic) of the Colorado Plateau, Hasiotis et al. (2004) described gently inclined, cylindrical burrows up to $50 \mathrm{~cm}$ in diameter and $200 \mathrm{~cm}$ long. They interpreted the Morrison burrows as 


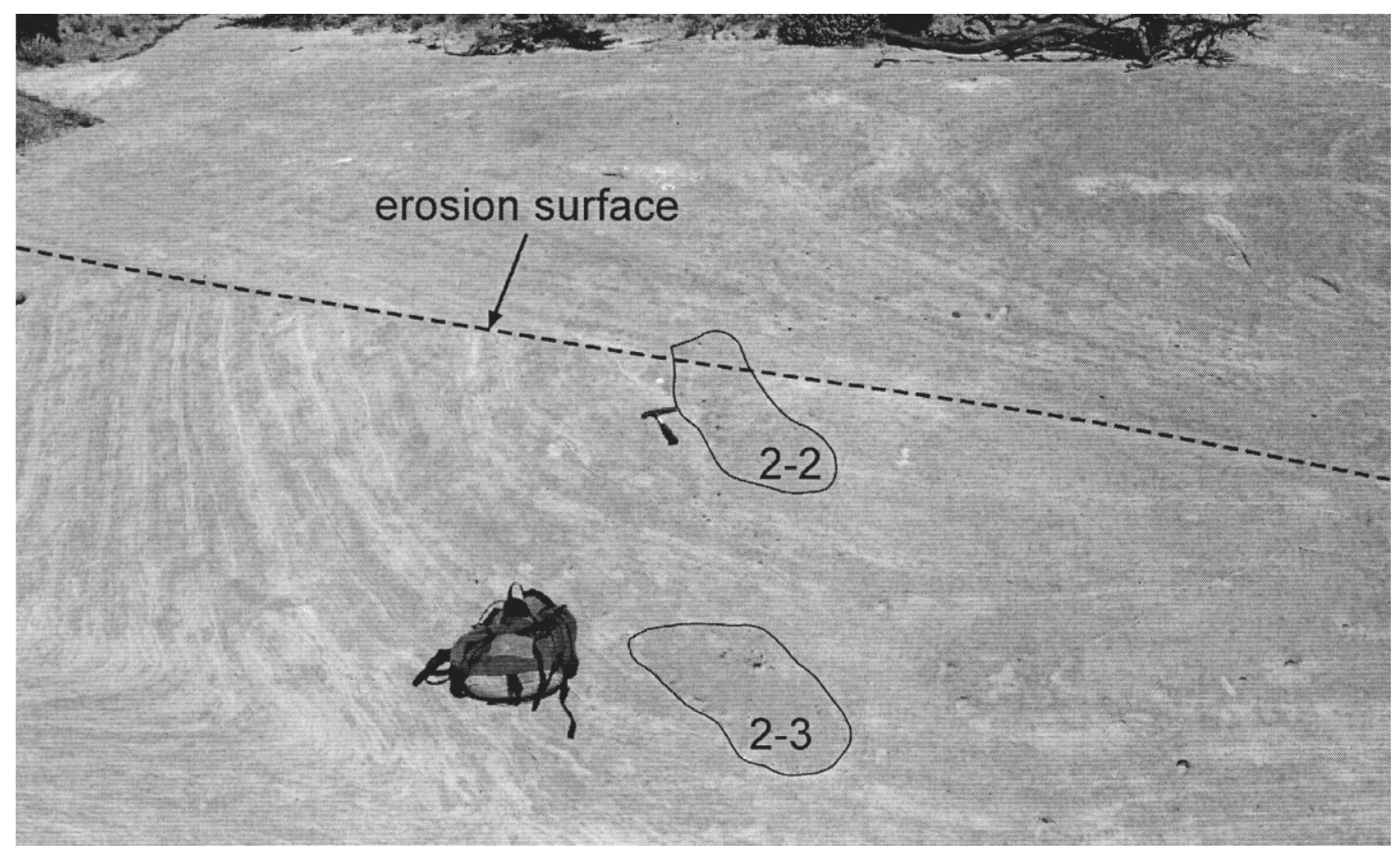

Figure 6. Erosion surface at site 2 that is cut by a burrow (2-2 in table 1$)$. The burrower penetrated the lower slope of a small dune that was migrating down the lee slope of a large dune ridge (fig. $4 a$ ). This burrow is about $10 \mathrm{~m}$ higher than the point where the erosion surface intersects the nearly horizontal (first-order) bounding surface at the base of the large dune ridge.

structures made near flowing water by crocodiles, sphenodontids, or turtles.

Many modern terrestrial vertebrates dig burrows for foraging, nesting, and sheltering (Reichman and Smith 1990; Kinlaw 1999). Modern subtropical dune fields, however, have the lowest animal biomass of any modern ecosystem. Deserts support a higher biomass of reptiles than of mammals because reptiles have lower metabolic rates (and are therefore better able to use resources that are patchily distributed in time and space). Moreover, reptiles can conserve water by eliminating nitrogen wastes via uric acid instead of urea (Pough 1980). In modern sand seas, most large animals are rare visitors that are incapable of long-term survival under average day-to-day conditions (Seely and Louw 1980; Louw and Seely 1982). At midday, the surficial sand can reach $80^{\circ} \mathrm{C}$ (Cloudsley-Thompson and Chadwick 1964), but because sand is a poor conductor of heat, the temperature is much cooler just $20 \mathrm{~cm}$ below the surface (Robinson and Seely 1980). Most animal life in subtropical deserts is therefore nocturnal and fossorial.

Four burrows at 20-Mile Wash (figs. 8, 9B) are distributed along a single gently dipping bedding plane that is here interpreted as a reactivation (third-order) surface (fig. 4b). It is not clear whether the burrowed sand below the erosion surfaces was moistened by rain that fell on the erosion surface or whether previously moistened sand was exhumed by the erosion event (Schenk et al. 1993). The only erosional surface that is cut by a burrow (fig. 6) is interpreted as a second-order surface (a diachronous surface generated by bedform migration and climb; fig. 4a).

Thorough searching of outcrops during this study revealed only 14 large burrows that penetrated seven different stratigraphic surfaces. In contrast, the same outcrops are replete with smaller, sinuous traces made in dry sand by sand-swimming reptiles (Loope 2005). Not only are the smaller traces much more abundant (very roughly estimated at 1000-10,000 within the same outcrops), but their distribution is also much denser in a stratigraphic sense: in one 1$\mathrm{m}$-thick section lying within a 6- $\mathrm{m}^{2}$ outcrop, scores of the smaller traces are present, and they terminate at 14 different surfaces (Loope 2005). The contrast in abundance and distribution suggests that permanent residents of the dune field made the small (dry sand) traces and that the large traces were made 


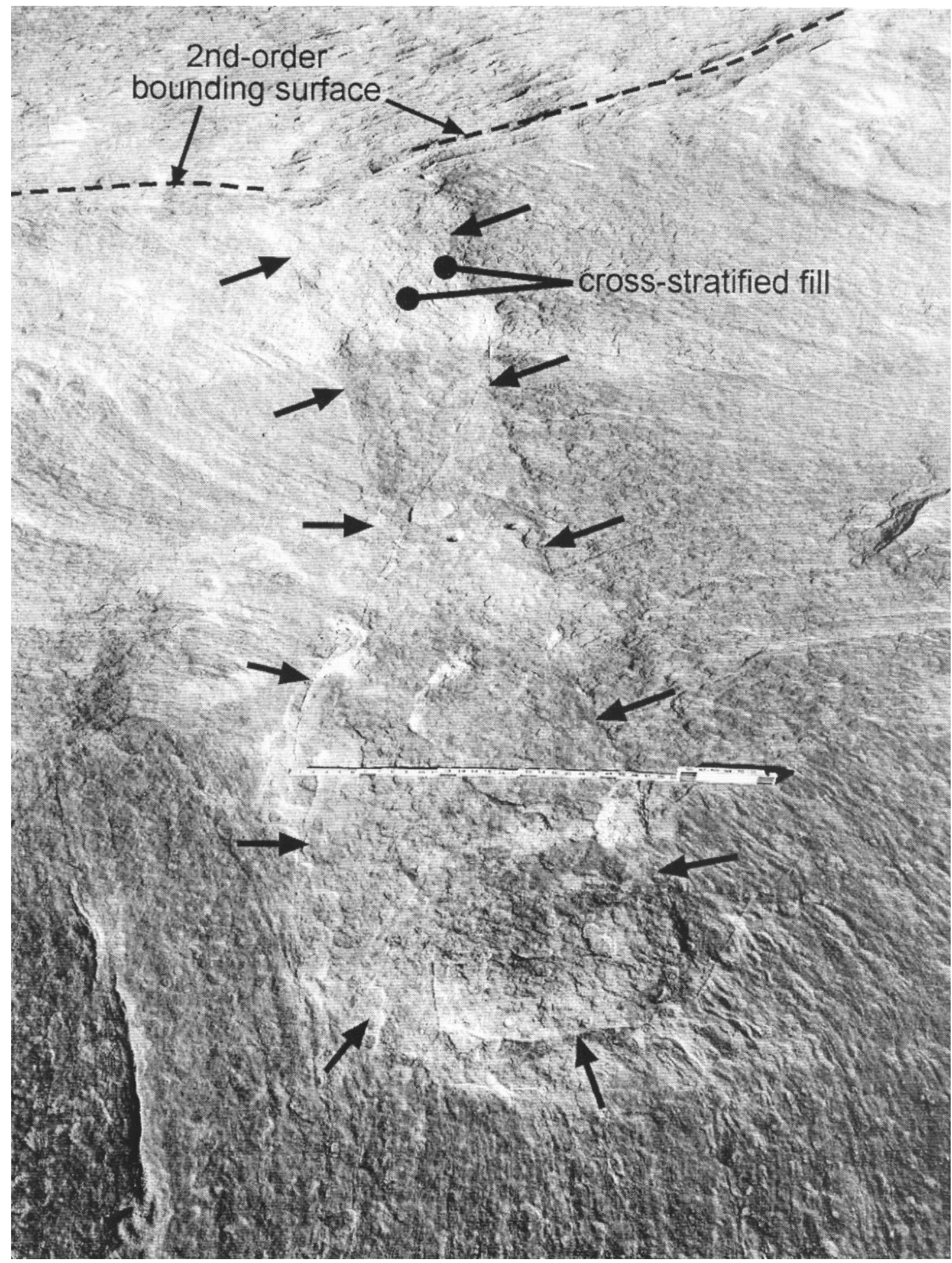

Figure 7. Longest burrow (3-5) found during this study, the only one with an expanded distal chamber. View is nearly horizontal; rock surface (and burrow) slopes toward the camera at about $20^{\circ}$. Chamber is $63 \mathrm{~cm}$ wide; burrow base is about $1.5 \mathrm{~m}$ below the bounding surface. Arrows delineate burrow margins. 

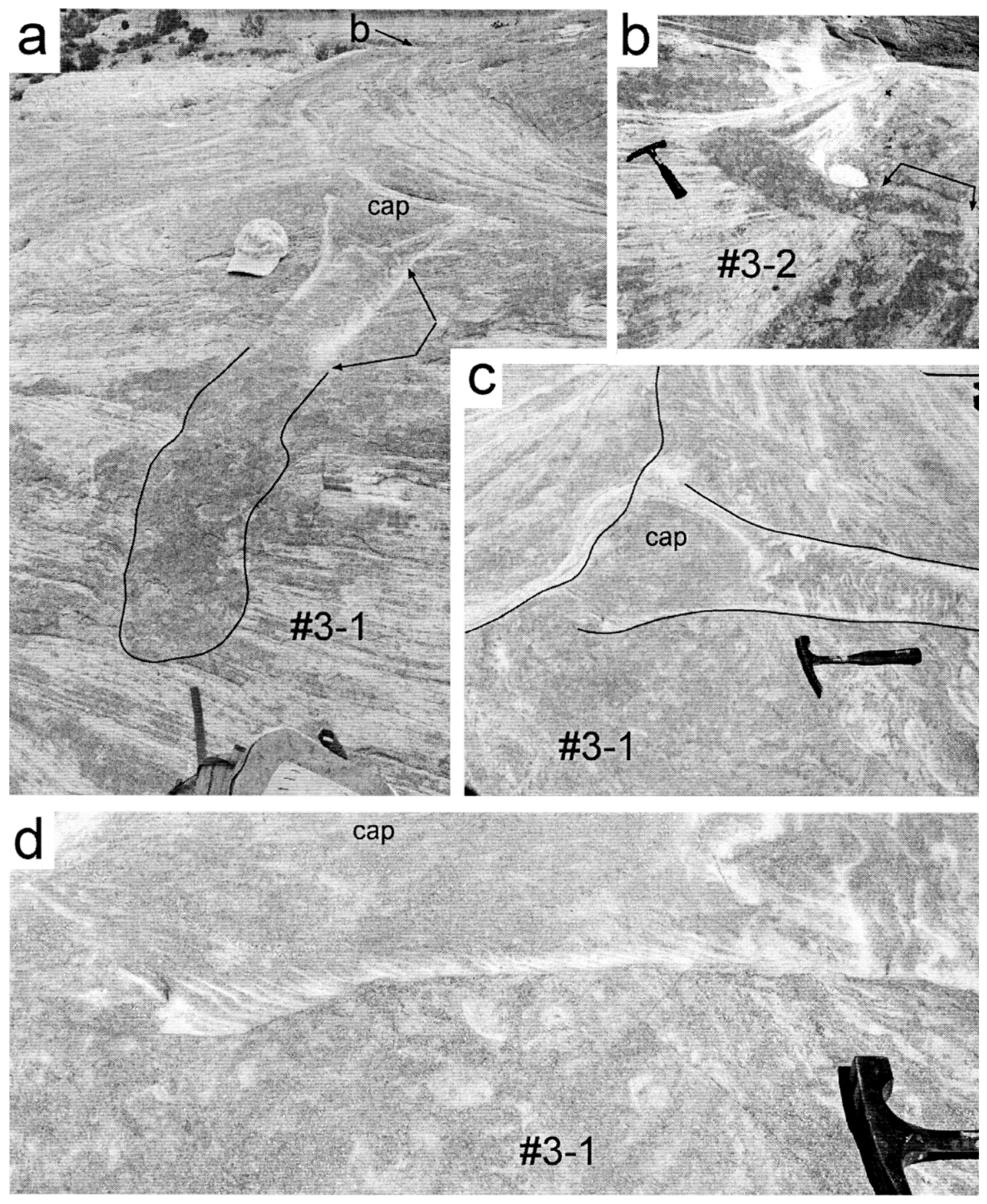

Figure 8. Cross-strata filling two burrows at site 3 oriented northwest-southeast. $a$, Note clearly delineated walls of upper burrow; arrows mark portion of burrow filled by eolian cross-strata. Location of another burrow (shown in $b$ ) is indicated by $b . b$, Burrow partially filled with eolian cross-strata. $c$, Lateral view of burrow in $a$; "cap" is composed of coarse-grained sand that preferentially accumulates during the last stage of burrow filling. $d$, Close-up of $c$ showing detail of eolian sand prograding into burrow left to right (northwest to southeast). 

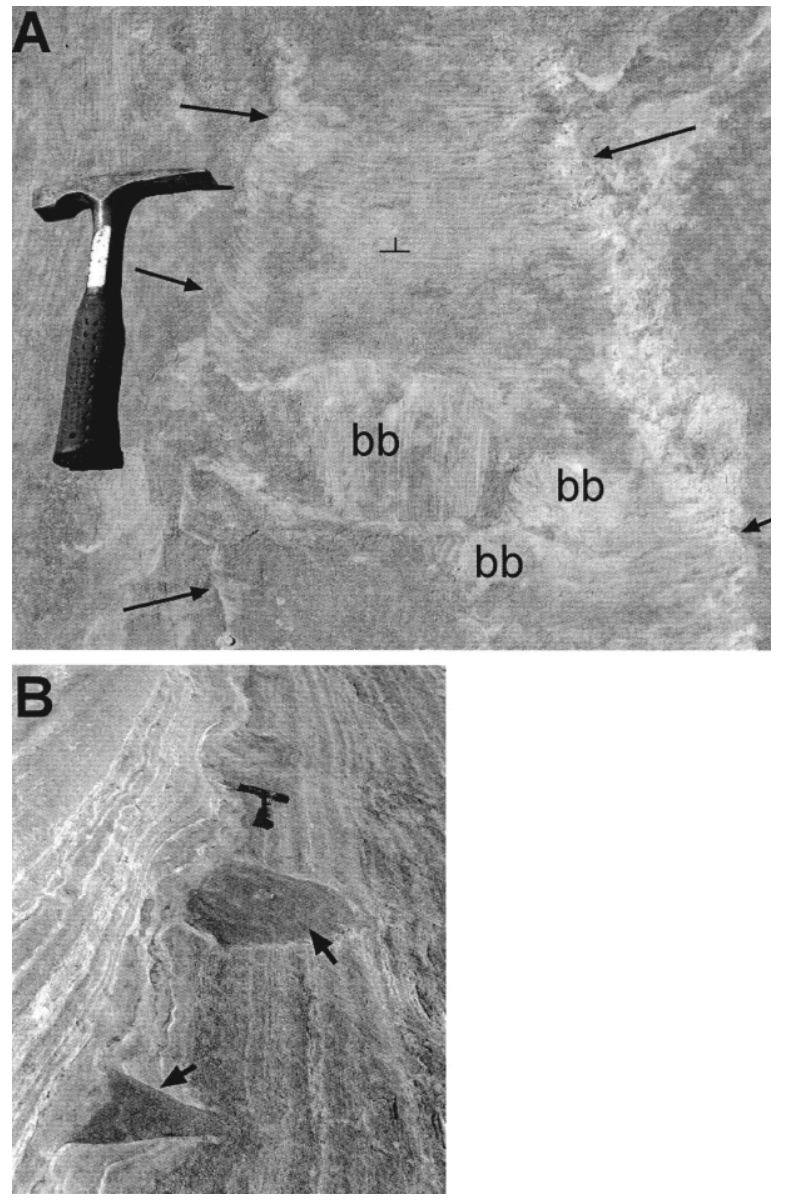

Figure 9. $A$, Breccia blocks $(b b)$ and eolian cross-strata within burrow 3-7 (table 1). Arrows delineate burrow margins. $B$, Poorly exposed burrows in which only the uppermost (capping), coarse-grained strata are visible. by either (1) opportunists that visited the dune field only on rare occasions (see Louw and Seely 1982, p. 138-139) or (2) resident animals that made excavations only on the rare occasions when a deeply moistened substrate was available.

\section{Conclusions}

Many of the animals that live in modern subtropical dune fields are fossorial. Because sand dunes lie above the water table, are unvegetated, and generate thin laminae during their relatively rapid migration, they are not only a good medium for burrowing but also well suited for preserving distinct, readily recognized burrows. Disruptions of the thin laminae are easily discerned, and because of dune migration and climb, the burrows are less likely to overlap than burrows that lie below unconformities and within paleosols. Although active dune fields may have small animal populations relative to other environments, the clearly delineated tunnels described here show that eolian dunes can provide an excellent medium for geologic preservation of the workings of fossorial animals.

\section{A C K N O W LED G M E N T S}

This project was funded by a research grant from the National Science Foundation (EAR02-07893). I thank C. Dumas for access to his land and for his hospitality and R. Irmis for sharing his knowledge of Jurassic vertebrates. D. Powell and A. Titus of Grand Staircase-Escalante National Monument provided helpful information and support.

\section{R E F E R E N C E S C I T E D}

Brookfield, M. E. 1977. The origin of bounding surfaces in ancient aeolian sandstones. Sedimentology 24:303332.

Buckle, C. 1996. Weather and climate in Africa. Harlow, Longman, $312 \mathrm{p}$.

Cloudsley-Thompson, J. L., and Chadwick, M. J. 1964. Life in deserts. London, Foulis, $218 \mathrm{p}$.

Doelling, H. H.; Blackett, R. E.; Hamblin, A. H.; Powell, J. D.; and Pollock, G. L. 2000. Geology of Grand Staircase-Escalante National Monument, Utah. In Sprinkel, D. A.; Chidsey, T. C.; and Anderson, P. B., eds. Geology of Utah's parks and monuments. Utah Geol. Assoc. Publ. 28:189-231.

Hasiotis, S. T.; Wellner, R. W.; Martin, A. J.; and Demko, T. M. 2004. Vertebrate burrows from Triassic and Jurassic continental deposits of North America and Antarctica: their paleoenvironmental and paleoecological significance. Ichnos 11:103-124.
Hildebrand, M. 1985. Digging of quadrupeds. In Hildebrand, M.; Bramble, D. M.; Liem, K. F.; and Wake, D. B., eds. Functional vertebrate morphology. Cambridge, MA, Harvard University Press, p. 89-109.

Hunt, A. P., and Lockley, M. G. 1995. A nonmarine tetrapod from the middle Jurassic of the United States: a primitive crocodyliform from the Entrada sandstone of eastern Utah. J. Vertebr. Paleontol. 15:554-560.

Irmis, R. B. 2005. A review of the vertebrate fauna of the lower Jurassic Navajo Sandstone in Arizona. In McCord, R. D., ed. Vertebrate paleontology of Arizona. Mesa Southwest Mus. Bull. 11:55-71.

Kinlaw, A. 1999. A review of burrowing by semi-fossorial vertebrates in arid environments. J. Arid Environ. 41: 127-145.

Kocurek, G. 1981. Significance of interdune deposits and bounding surfaces in aeolian dune sands. Sedimentology 28:753-780. 
ed. 1988. Late Paleozoic and Mesozoic eolian deposits of the western interior of the United States. Sediment. Geol. 56, 413 p.

Lockley, M. G. 1998. The vertebrate track record. Nature 396:429-432.

Lockley, M. G., and Hunt, A. P. 1995. Dinosaur tracks and other fossil footprints of the western United States. New York, Columbia University Press, 338 p.

Loope, D. B. 1984. Eolian origin of upper Paleozoic sandstones, southeastern Utah. J. Sediment. Petrol. 54: 563-580.

2005. Abundant traces of sand-swimming reptiles preserved in cross-strata deposited high on the flanks of Jurassic dunes. Geol. Soc. Am. Abstr. Program 7: 339.

2006. Dry-season tracks in dinosaur-triggered eolian grainflows. Palaios 21:132-142.

Loope, D. B., and Rowe, C. M. 2003. Long-lived pluvial episodes during deposition of the Navajo Sandstone. J. Geol. 111:223-232.

Loope, D. B.; Rowe, C. M.; and Joeckel, R. M. 2001. Annual monsoon rains recorded by Jurassic dunes. Nature 412:64-66.

Loope, D. B.; Steiner, M. B.; Rowe, C. M.; and Lancaster, N. 2004. Tropical westerlies over Pangaean sand seas. Sedimentology 51:315-322.

Louw, G. N., and Seely, M. K. 1982. Ecology of desert organisms. New York, Longman, $194 \mathrm{p}$.

McKee, E. D. 1934. The Coconino Sandstone: its history and origin. Carnegie Inst. Wash. Publ. 440:77-115.

Pough, F. H. 1980. The advantages of ectothermy for tetrapods. Am. Nat. 115:92-112.

Pye, K., and Tsoar, H. 1990. Aeolian sand and sand dunes. London, Unwin Hyman, 396 p.

Reichman, O. J., and Smith, S. C. 1990. Burrows and burrowing behavior by mammals. Curr. Mammal. 2: 197-244.

Robinson, M. D., and Seely, M. K. 1980. Physical and biotic environments of the southern Namib dune ecosystem. J. Arid Environ. 3:183-203.

Schenk, C. J.; Gautier, D. L.; Olhoeft, G. R.; and Lucas, J. E. 1993. Internal structure of an Aeolian dune using ground-penetrating radar. In Pye, K., and Lancaster, N., eds. Aeolian sediments: ancient and modern. Int. Assoc. Sedimentol. Spec. Publ. 16:61-69.

Seely, M. K., and Louw, G. N. 1980. First approximation of the effects of rainfall on the ecology and energetics of a Namib Desert dune ecosystem. J. Arid Environ. 3:23-54.

Smith, R. M. H. 1987. Helical burrow casts of therapsid origin from the Beaufort Group (Permian) of South Africa. Palaeogeogr. Palaeoclimatol. Palaeoecol. 60: 155-170.

Steiner, M. B. 2003. A cratonic Middle Jurassic paleopole: Callovian-Oxfordian stillstand (J-2 cusp), rotation of the Colorado Plateau, and Jurassic North American apparent polar wander. Tectonics 22:1020.

Thompson, A. E., and Stokes, W. L. 1970. Stratigraphy of the San Rafael Group, southwest and south central Utah. Utah Geol. Mineral. Surv. Bull. 87, 53 p.

Voorhies, M. R. 1975. Vertebrate burrows. In Frey, R. W., ed. The study of trace fossils. New York, Springer, p. 325-350.

Winkler, D. A.; Jacobs, L. L.; Congleston, J. D.; and Downs, W. R. 1991. Life in a sand sea: biota from Jurassic interdunes. Geology 19:889-892.

Yan, Z., and Petit-Maire, N. 1994. The last $140 \mathrm{Ka}$ in the Afro-Asian arid/semi-arid transitional zone. Palaeogeogr. Palaeoclimatol. Palaeoecol. 110:217-233. 